\title{
Biological and molecular characterization of a highly divergent johnsongrass mosaic virus isolate from Pennisetum purpureum
}

\author{
Karina N. Silva ${ }^{1} \cdot$ Fernando L. Melo $^{1} \cdot$ Anelise F. Orílio $^{1} \cdot$ Tatsuya Nagata $^{1} \cdot$ \\ Marilia S. Silva $^{2}$ - Celso D. Fernandes ${ }^{3} \cdot$ Rodrigo R. Fragoso $^{4} \cdot$ Suelen N. Dessaune $^{4}$. \\ Renato O. Resende ${ }^{1}$
}

Received: 14 November 2015/Accepted: 15 March 2016/Published online: 21 April 2016

(c) Springer-Verlag Wien 2016

\begin{abstract}
The complete genome sequence $(9,865$ nucleotides) of a highly divergent johnsongrass mosaic virus isolate (JGMV-CNPGL) was determined using Illumina sequencing. This isolate infected 10 genotypes of gramineous plants including maize. A comparative analysis of the complete genome showed $80 \%$ nucleotide (nt) sequence identity ( $86 \%$ amino acid (aa) sequence identity) to a johnsongrass mosaic virus isolate from Australia. The coat protein $(\mathrm{CP})$ identity values, however, were lower than those for the whole genome (78\% and $80 \%$ for nt and aa, respectively) and were close to the species demarcation values $(77 \% \mathrm{nt}$ and $80 \%$ aa). Unexpectedly, the aminoterminal portion of CP of JGMV-CNPGL showed only $38 \%$ sequence identity to other JGMV isolates. The biological implications of this sequence divergence remain to be elucidated.
\end{abstract}

Elephant grass (Pennisetum purpureum) is a perennial grass species belonging to the family Poaceae, which

Electronic supplementary material The online version of this article (doi:10.1007/s00705-016-2832-9) contains supplementary material, which is available to authorized users.

Renato O. Resende

rresende@unb.br

1 Department of Cell Biology, University of Brasilia, Campus Universitário Darcy Ribeiro, Brasília, Distrito Federal 70910-900, Brazil

2 Embrapa Genetic Resources and Biotechnology, Brasília, Distrito Federal, Brazil

3 Embrapa Beef Cattle, Campo Grande, Mato Grosso do Sul, Brazil

4 Embrapa Cerrado, Planaltina, Distrito Federal, Brazil includes maize, sorghum, wheat, rice, oat, barley, millet, brachiaria and panicum. Elephant grass, also known as napier grass, was first described in 1827 by Heinrich Schumacher in Africa, where this species originated [1]. The introduction of elephant grass into Brazil occurred in 1920, and this plant adapted to different soil types, except for poorly drained soils [2]. In the last 15 years, it has been used for feeding cattle due to its nutritional quality and yield [3]. The potential of elephant grass as a biomass source for bioethanol production has also been recognized [4].

Elephant grass is propagated by vegetative means using mature stems [3], an agricultural practice that favors the accumulation of viruses in crop plants (?references?). Until now, viruses of three genera (Potyvirus, Mastrevirus, and Sobemovirus) and an unclassified virus of the family $\mathrm{Lu}$ teoviridae have been reported to infect elephant grass worldwide. In Brazil, johnsongrass mosaic virus has been reported recently by our research group [5].

Johnsongrass mosaic virus (JGMV) belongs to the genus Potyvirus (family Potyviridae), causing mosaic symptoms and severe yield losses in several monocot species. This virus is transmitted in a non-persistent manner by some aphid species: Aphis craccivora, Aphis gossypii, Myzus persicae and Rhopalosiphum maidis [6, 7]. JGMV was first described in Australia as maize dwarf mosaic virus [8] and later as a johnsongrass strain of sugarcane mosaic virus based on its biological and serological properties [7, 9]. However, Shukla and Ward [9] demonstrated, based on nucleotide and amino acid sequences of the coat protein (CP), that this virus was indeed a member of a new potyvirus species, which was given the name Johnsongrass mosaic virus. Previous reports have demonstrated the occurrence of this virus in Australia [8, 10, 11], South America [5, 12, 13], Nigeria [14] and the USA [6, 15]. In 
the USA, JGMV was first isolated in Texas and described as an MDMV isolate capable of infecting oat, johnsongrass and maize [6]. Now, this strain is designated as JGMVMDO (maize dwarf oat strain) [15]. JGMV has also been reported in Venezuela infecting several varieties of maize $[12,16]$ and in Colombia infecting Brachiaria spp. (JGMV-Brac) [13]. A distinct JGMV isolate in Brazil infecting Pennisetum purpureum was reported previously by our group, and its $\mathrm{CP}$ gene was sequenced [5].

Here, we have investigated the biological characteristics of this Brazilian JGMV isolate, hereafter designated as JGMV-CNPGL (Centro Nacional de Pesquisa de Gado de Leite strain), and determined its complete genome sequence. Potyvirus-like flexuous and filamentous viral particles were observed in leaves of $P$. purpureum. Leaf tissues were fixed with $2 \%$ phosphotungstic acid and then examined by transmission electron microscopy (Fig. 1A). The host range and symptomatology of this virus were determined by mechanical inoculation of infected leaf extracts (Fig. 1C) into 14 putative host plants. These plants were kept in greenhouse conditions and monitored for 30 days for the appearance of symptoms. The first symptoms were observed 13 days post-inoculation (dpi), and the infection was confirmed by RT-PCR using specific primers JG8352-F (CAAAGCCCCATACTTGTCGG) and JG9413$\mathrm{R}$ (TTAGCCCCACGGTATGAATG). Ten inoculated plants were susceptible to JGMV-CNPGL, showing two main types of symptoms: chlorotic veins observed in Zea mays 2B587, Zea mays 3646H1(Fig. 1B) and Pennisetum glaucum (Millet ADR500) and mosaic symptoms in
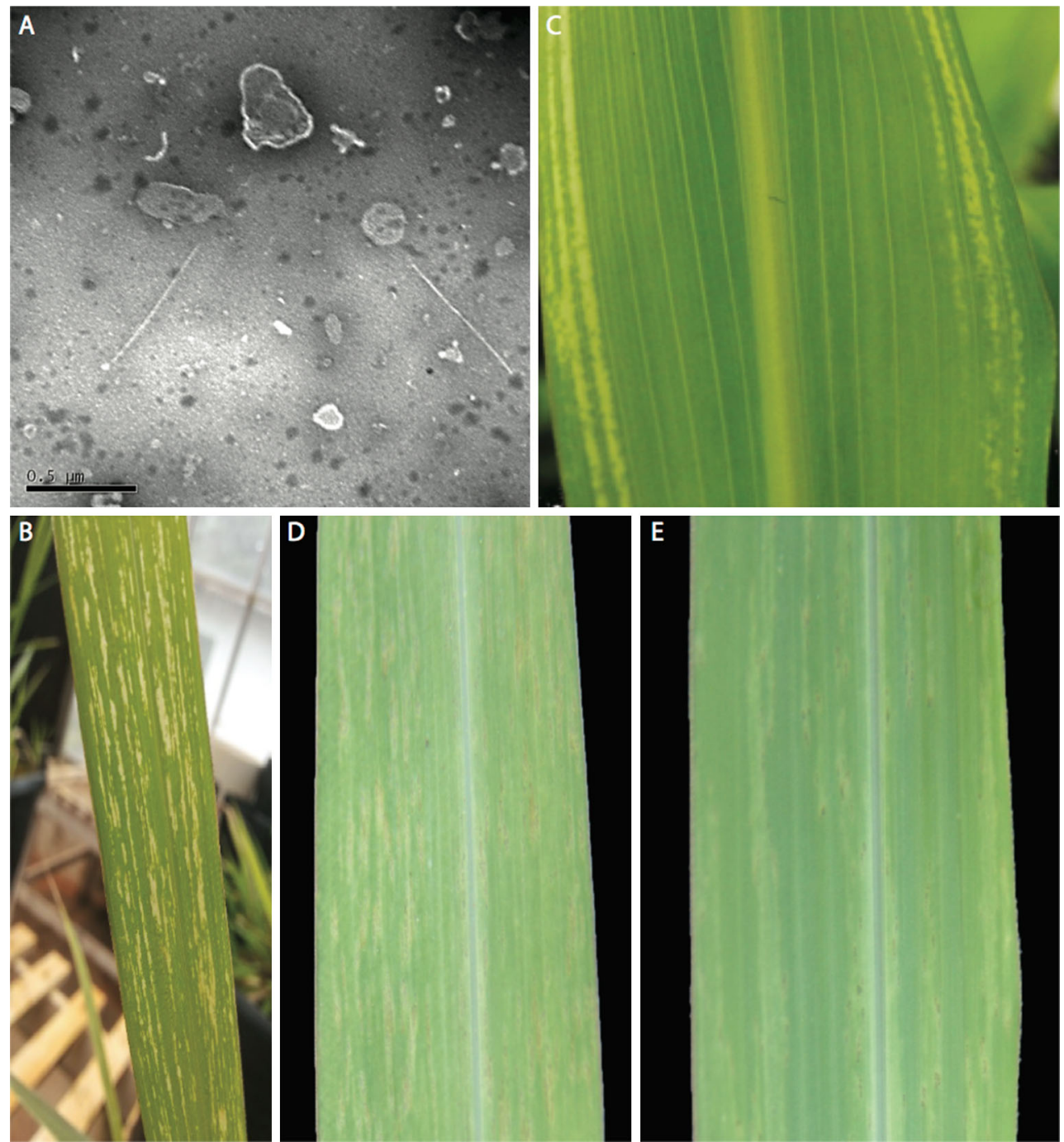

Fig. 1 (A) Virus particles of johnsongrass mosaic virus isolate JGMV-CNPGL (Centro Nacional de Pesquisa de Gado de Leite strain) infecting Pennisetum purpureum. (B) Symptoms of isolate JGMV-CNPGL in Zea mays 3646H1. (C) Symptoms induced by the

JGMV-CNPGL isolate in Pennisetum purpureum. (D) Symptoms of isolate JGMV-CNPGL in Panicum maximum cv. Mombaça; (E) Symptoms of isolate JGMV-CNPGL in Sorghum bicolor BRS332 


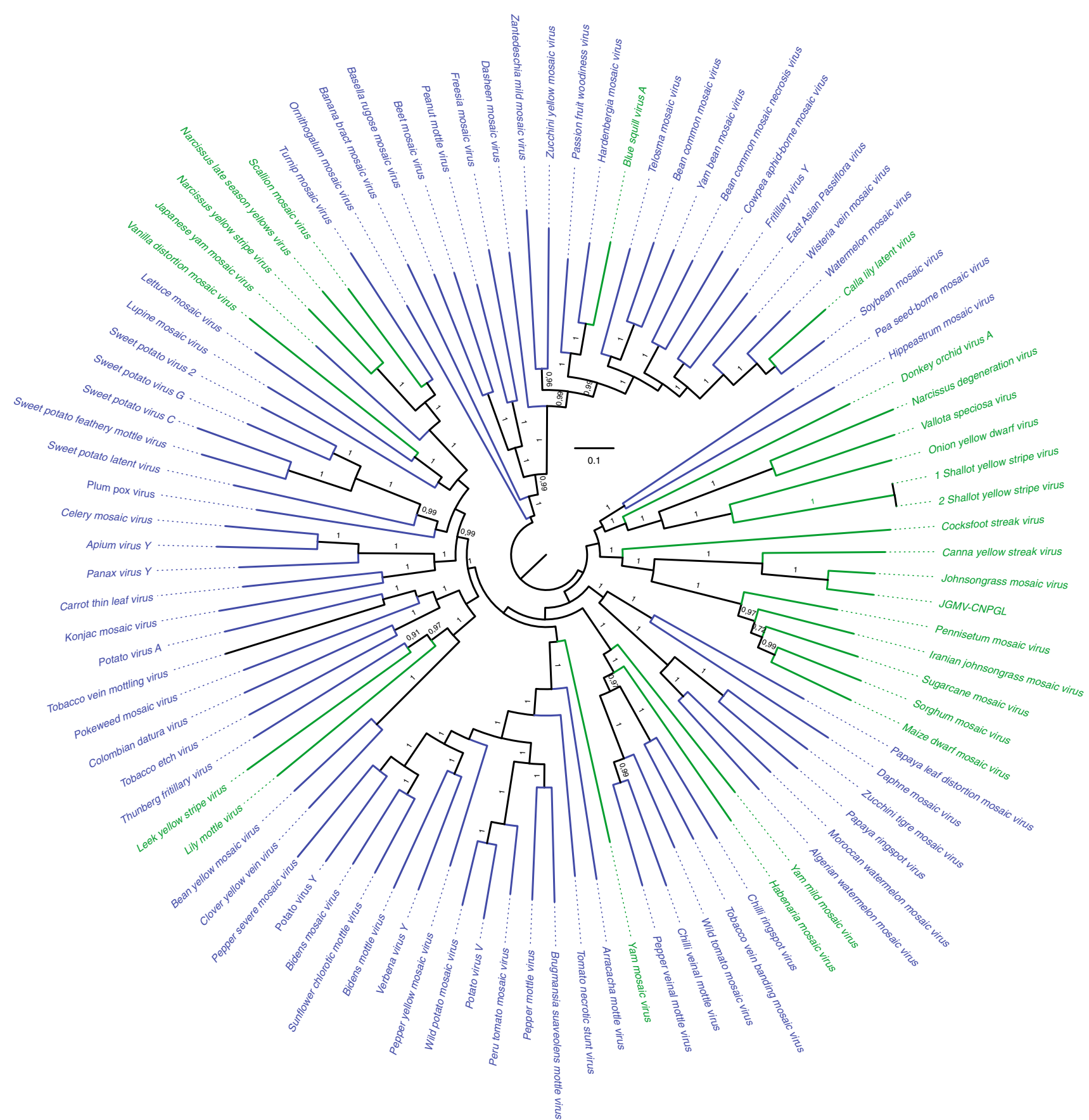

Fig. 2 Phylogenetic analysis using nucleotide sequences of the polyprotein region of potyviruses. The blue color indicates viruses that infect dicotyledonous plants, and the green color indicates viruses infecting monocots. The complete nucleotide sequence of JGMV-

Brachiaria brizantha cv. Arapoty, Brachiaria brizantha cv. Xaraés, Panicum maximum cv. Mombaça (Guineagrass) (Fig. 1D), Panicum maximum cv. Massai, Panicum maximum C12, BRS Capileto, and Sorghum bicolor BRS332 (Fig. 1E). JGMV-CNPGL did not infect Triticum aestivium BRS264 (wheat), Hordeum vulgare L. VCU-CPAC (barley), Crotalaria juncea or Glycine max (soybean) under

CNPGL ORF1 was aligned with other potyvirus sequences (Supplementary Table 1) using the translation alignment tool implemented in Geneious 9.1. The phylogenetic tree was inferred using the FastTree algorithm implemented in Geneious 9.1 (color figure online)

greenhouse conditions. The JGMV-CNPGL host range was similar to that reported for JGMV-N [14] and JGMV-MDO [15]. More importantly, JGMV-CNPGL infected maize, suggesting that this virus represent a potential threat to this crop in Brazil, one of the largest maize producers.

For genome sequencing of JGMV-CNPGL, viral particles were partially purified as follows. Infected leaves were 


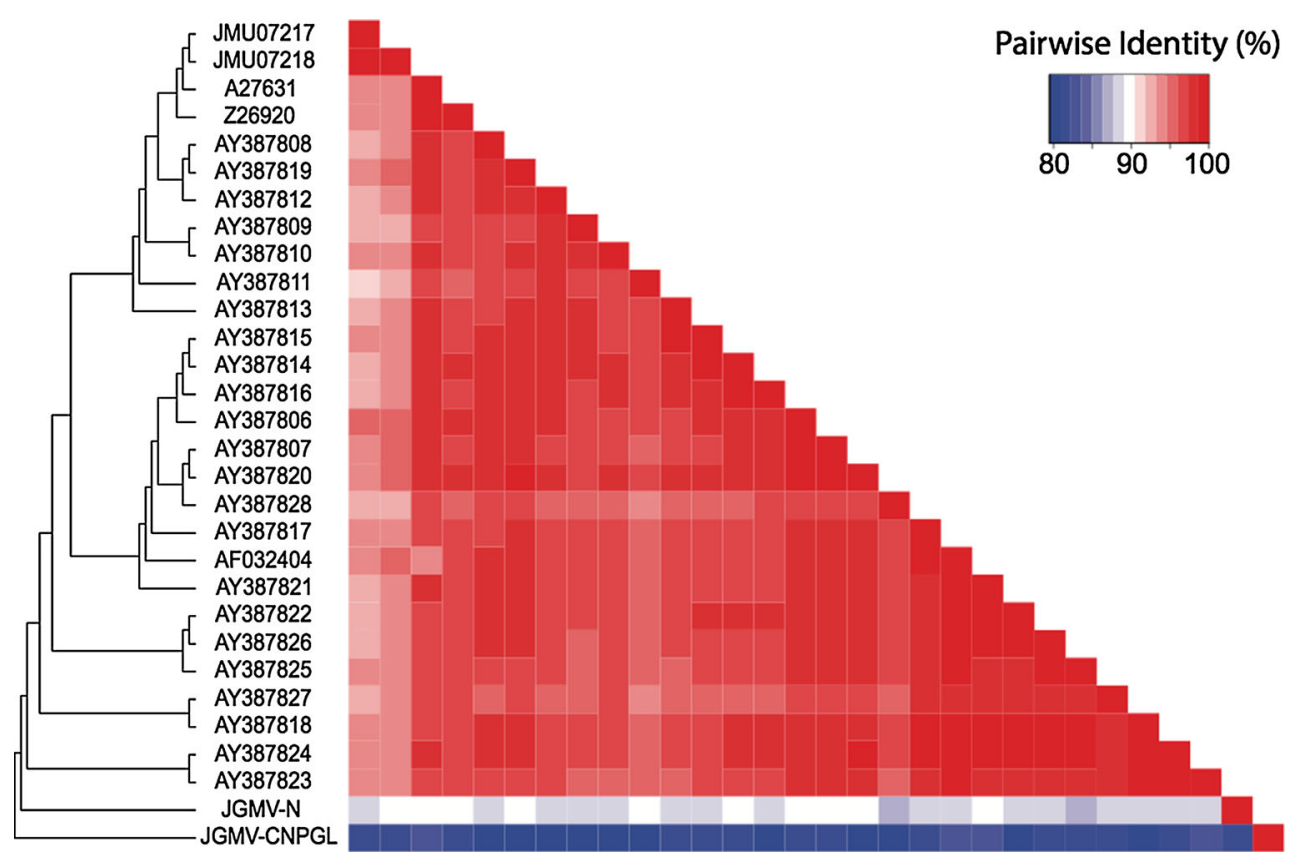

Fig. 3 Pairwise comparison matrix of $\mathrm{CP}$ protein sequences from several JGMV isolates. The identity values are presented in the lower triangular matrix, ordered according to the phylogenetic tree. The color represents the identity values (blue to red). The Brazilian isolate (JGMV-CNPGL) was compared to other JGMV sequences from the GenBank database, originating from Australia (A27631, Z26920,
AF032404, AY387806-AY387828), the USA (JMU07217 and JMU07218J) and Nigeria (P83574J). The phylogenetic tree was inferred using the same dataset, and the branches were proportionally transformed using FigTree v. 1.4.2 (available at http://tree.bio.ed.ac. uk/software/figtree/) (color figure online)

first ground in liquid nitrogen, then homogenized in PBSEDTA and $\beta$-mercaptoethanol, and filtered with cheesecloth. The filtrate was then centrifuged through a sucrose cushion at $33,000 \times g$ for $2 \mathrm{~h}$, and the pellet was resuspended in PBS. From this enriched virus fraction, total RNA was extracted using an RNeasy Plant Mini Kit (QIAGEN, Valencia, CA), following the manufacturer's manual. RNA samples were sequenced at Catholic University of Brasilia (UCB) using a Nextera DNA Library Preparation Kit and an Illumina MiSeq platform. The paired-ends reads $(7,402,180)$ were quality-filtered, the adapter sequences were removed, and contigs were assembled de novo using CLC Genomics Workbench version 6.0.3. The assembled contigs were compared using blastx against the Viral RefSeq database, and contigs related to JGMV were selected and mapped to the reference genome of JGMV (NC-003606). The complete genome sequence was 9,865 nucleotides (nt) long with two open reading frames (ORFs), and 28,967 reads aligned back to it. ORF1, which encompasses 9,414 nt, encodes a large polyprotein consisting of 3,059 amino acids (aa). After proteolytic cleavage, the proteins P1, HC-Pro, P3, 6K1, CI, 6K2, VPg, NIa-pro, NIb and CP are predicted. ORF2 (2,793-3,068 nt), embedded in the P3 cistron, encodes the P3N+PIPO protein (91aa), which was identified by the presence of the conserved motif $\mathrm{G}_{1} \mathrm{~A}_{6}$. Several motifs previously reported to be conserved among potyviruses have been found, including HXDGXSG and FIIRGR in P1 [17], GDD in NIb, Y/FK/RNK in HC-Pro [18] and DAG in the CP. However, the KITC motif of HCPro, which is involved in the interaction of the viral particle and the stylus [19], is absent in the JGMV-CNPGL isolate. The lack of this conserved motif has been reported for other potyviruses such as soybean mosaic virus [20] and wisteria vein mosaic virus [21]. The 5' and 3' untranslated regions (UTR) were $237 \mathrm{nt}$ and $451 \mathrm{nt}$ long, respectively, and both were confirmed by RACE. The JGMV-CNPGL genome was deposited under GenBank accession number KT833782.

The complete nucleotide sequence of JGMV-CNPGL ORF1 was aligned with other potyvirus sequences (Supplementary Table 1) using the translation alignment tool implemented in Geneious 7.1 [22]. As shown in Fig. 2, JGMV isolates clustered with canna yellow streak virus. All the viruses grouped in this clade infect only monocots, suggesting an ancestral adaptation towards these hosts. A comparison of the JGMV-CNPGL genome sequence with those of other potyviruses revealed highest nucleotide sequence identity ( $80 \%$ nt and $86 \%$ aa) to a JGMV isolate from Australia (NC-003606). The nucleotide sequence identity between these viruses was $70 \%$ for $\mathrm{P} 1,76 \%$ for HC-Pro, $85 \%$ for P3, $86 \%$ for $6 \mathrm{~K} 1,83 \%$ for CI, $83 \%$ for 
$6 \mathrm{~K} 2,81 \%$ for $\mathrm{VPg}, 84 \%$ for NIa-pro, $85 \%$ for NIb, $78 \%$ for CP, $41 \%$ for 5'UTR and $85 \%$ for 3'UTR. Figure 3 presents the full comparison matrix sequence and phylogenetic analysis based on $\mathrm{CP}$ aa sequences of JGMVCNPGL and other JGMV isolates from three different countries (Australia, United States and Nigeria).

To establish a new potyvirus species, its members must share CP identity values lower than 76-77\% nt and $80 \%$ aa. The identity between the CP of JGMV-CNPGL and JGMV Australian isolate was $78 \%$ nt and $82 \%$ aa, respectively, slightly above the threshold for new species demarcation [23]. Although these two isolates belong to the same species, the N-terminal region of CP from JGMVCNPGL is highly divergent in the region from aa residues 9 to 85 , showing only $38 \%$ identity in this region. Interestingly, another JGMV isolate infecting Panicum maximum was recently reported in Brazil (GenBank accession number 289893). Although this isolate shares $80 \%$ sequence identity with JGMV Australia, it cannot infect $P$. purpureum and maize, unlike JGMV-CNPGL. These observations indicate that these differences among JGMV isolates lead to biological variations regarding host range, for instance. The implications of this amino-terminal variation in JGMV-CNPGL remain to be investigated. Considering that $P$. purpureum and $P$. maximum originated in Africa, it is reasonable to assume that JGMV also emerged in the same area. More-intense sampling efforts may help to understand its evolutionary history and adaptations to distinct hosts.

Acknowledgments We want to acknowledge Dr. Francisco José da Silva Ledo for providing the infected Pennisetum purpureum plants, and Dr. Francisco Duarte Fernandes and Ivanilson Luis Lopes da Silva for providing the seeds for experimental inoculation. This work was financially supported by the National Council for Science and Technology (CNPq), Coordination for the Improvement of Higher Education Personnel (CAPES), Foundation for Research Support of the Distrito Federal (FAP-DF) and the Brazilian Agricultural Research Corporation (Embrapa).

\section{Compliance with ethical standards}

This work was financially supported by the National Council for Science and Technology (CNPq), Coordination for the Improvement of Higher Education Personnel (CAPES), Foundation for Research Support of the Distrito Federal (FAP-DF) and the Brazilian Agricultural Research Corporation (Embrapa). All authors declare they have no conflict of interest. This article does not contain any studies with human participants or animals performed by any of the authors.

\section{References}

1. Araújo SAC, Deminicis BB, Campos PRS (2008) Melhoramento Genético de Plantas Forrageiras Tropicais no Brasil. Arch Zootec $57: 61-76$
2. Bennet HW (1976) Pasto Johnson, pasto alfombra y otras gramíneas para el sur humedo de los Estados Unidos. In: Hugues HD, Heath ME, Metcalfe DS (eds) Forrajes, México, C.E.C.S.A., pp 321-334

3. Wayne WH, Warren GM (1980) Yield, quallity, and breeding behavior of Pearl Millet X Napiergrass interspecific hybrids. Agron J 72:358-360

4. Yasuda M, Ishii Y, Ohta K (2014) Napier Grass (Pennisetum purpureum Schumach) as raw material for bioethanol production: pretreatment, saccharification, and fermentation. Biotechnol Bioprocess Eng 19:943-950

5. Silva KN, Nicolini C, Silva MS, Fernandes CD, Nagata T, Resende RO (2013) First report of Johnsongrass mosaic virus (JGMV) infecting Pennisetum purpureum in Brazil. Plant Dis 97:1003

6. McDaniel LL, Gordon DT (1989) Characterization of the oatinfecting strain of maize dwarf mosaic virus. Phytopathology 79:113-120

7. Teakle DS, Grylls NE (1973) Four strains of sugarcane mosaic virus infecting cereals and other grasses in Australia. Aust J Agric Res 24:465-477

8. Shukla DD, Gough KH, Ward CW (1987) Coat protein of potyviruses: comparison of amino acid sequences of the coat proteins of four Australian strains of sugarcane mosaic virus. Arch Virol 96:59-74

9. Taylor RH, Pares RD (1968) The relationship between sugarcane mosaic virus and mosaic virus maize and Johnson grass in Australia. Aust J Agric Res 19:767

10. Gough KH, Shukla DD (1993) Nucleotide sequence of Johnsongrass mosaic Potyvirus genomic RNA. Intervirology 36:181-192

11. Karan M, Noone DF, Teakle DS, Hacker JB (1992) Susceptibility of pearl millet accessions and cultivars to Johnsongrass mosaic and sugarcane mosaic viruses in Queensland. Aust Plant Pathol 21:128-130

12. Mariño AA, Garrido MJ, Ascanio A (2009) Reaccoín de cultivares de maíz al Potyvirus del mosaic del pasto Johnson. Fitopatologia Venezuela. 22:35-36

13. Morales FJ, Ospina MD, Castaño M, Calvert LA (1996) Sequence analysis of the genomic RNA3-terminal region of a potyvirus from Brachiaria spp. related to Guineagrass mosaic virus. J Phytopathol 144:485-489

14. Seifers DL, Haber S, Ens W, She YMK, Standing G, Salomon R (2005) Characterization of a distinct Johnsongrass mosaic virus strain isolated from sorghum in Nigeria. Arch Virol. 150:557-576

15. Shukla DD, Ward CW (1989) Identification and classification of potyviruses on the basis of coat protein sequence data and serology. Arch Virol 106:171-200

16. Garrido MJ, Trujillo GE (1993) Occurrence of Johsongrass mosaic virus on sorghum in Venezuela. Plant Dis 77:847

17. Verchot J, Herndon KL, Carrington JC (1992) Mutational anal$\mathrm{ysis}$ of the tobacco etch potyviral $35-\mathrm{kDa}$ proteinase: identification of essential residues and requirements for autoproteolysis. Virology 190:298-306

18. Shiboleth YM, Haronsky E, Leibman D, Arazi Tzahi, Wassenegger M, Whitham SA, Gaba V, Amit Gal-On A (2007) The conserved FRNK box in HC-Pro, a plant viral suppressor of gene silencing, is required for small RNA binding and mediates symptom development. J Virol 81:13135-13148

19. Blanc S, Ammar ED, Garcia-Lampasona S, Dolja VV, Llave C, Baker J, Pirone TP (1998) Mutations in the potyvirus helper component protein: effects on interaction with virions and aphid stylets. J Gen Virol 79:3119-3122

20. Jayaram Ch, Hill JH, Miller AW (1992) Complete nucleotide sequences of two soybean mosaic virus strains differentiated by 
response of soybean containing the Rsv resistance gene. J Gen Virol 73:2067-2077

21. Liang WX, Song LM, Tian GZ, Li HF, Fan ZF (2006) The genomic sequence of Wisteria vein mosaic virus and its similarities with other potyviruses. Arch Virol 151(11):2311-2319

22. Kearse M, Moir R, Wilson A, Stones-Havas S, Cheung M, Sturrock S, Buxton S, Cooper A, Markowitz S, Duran C, Thierer
T, Ashton B, Meintjes P, Drummond A (2012) Geneious basic: an integrated and extendable desktop software platform for the organization and analysis of sequence data. Bioinf Appl Note 28:647-1649

23. Adams MJ, Antoniw JF, Fauquet CM (2005) Molecular criteria for genus and species discrimination within the family Potyviridae. Arch Virol 150:459-479 